\title{
АДВОКАТУРА В СИСТЕМІ ОРГАНІВ ПРАВОСУДДЯ
}

\author{
ПОПАДИНЕЦЬ Галина Олександрівна - кандидат філософських наук, \\ доцент кафедри кримінального права і процесу Інституту права, психології та \\ інноваційної освіти Національного університету «Львівська політехніка" \\ ORCID ID: 0000-0003-1701-0830 \\ ГЛИВЧАК ОЛьга - студентка Інституту права, психології та інноваційної \\ освіти Національного університету «Львівська політехніка"
}

УДК 347.93.004.77

DOI 10.32782/NP.2021.4.18

Стаття присвячена питанню визначення місия адвокатури у системі органів правосуддя. Актуальність извого питання стала наслідком прийняття в червні 2016 року Закону України «Про внесення змін до Конституий Украӥни (щодо правосуддя)» від 02.06.2016 № 1401-VIII, яким інститут адвокатури віднесено до правосуддя.

Зазначено, шо адвокатура Украӥни є недержавним самоврядним інститутом, що забезпечує здійснення захисту, представництва та надання інших видів правової допомоги на професійній основі, а також самостійно вирішує питання організаиіӥ $і$ діяльності в порядку, встановленому законодавством. Адвокатсъка діяльність забезпечує публічний інтерес, тобто інтерес суспільства в иілому, иляхом обстоювання приватного інтересу конкретної особи, а отже, сприяє правосуддю.

На адвокатуру покладається ряд завдань, головними з яких $є$ забезпечення кваліббікованою юридичною допомогою кожного, хто ї потребує, дотримання і зміцнення законності та неухильного їх виконання у різних напрямках діяльності - від надання консультаизй до захисту у кримінальному провадженні i представництва у цивільних, господарсъких та адміністративних справах.

Визначення адвокатсъкої пробесіи, як «вільної», $е$ в певній мірі умовним, оскільки мета цього інституту - захищати приватних осіб у правовому спорі з державою, виконуючи публічно-правові фбункиії. Единою $і$ головною відмінністю адвокатури, як суб'єкта надання правової допомоги, $е$ адвокатсъкий статус і гарантї адвокатсъкої діяльності. Особливий статус адвокатури повинен забезпечувати ебективнішу правову допомогу адвоката порівняно з юридичними послугами інших суб'єктів. Незалежна судова система може бути створена лише за наявності дійсно незалежної адвокатури. Дискусійним питанням діяльності адвокатури залишається доиільність запровадження адвокатсъкой монополї та ї̈ вплив на здійснення правосуддя.

Надання адвокатами професійної правової допомоги є необхідною умовою реалізащій правосуддя, тому інститут адвокатури у системі органів правосуддя є ї̈ невід'ємною иастиною.

Ключові слова: адвокатура, адвокатсъка діяльність, судова реборма, статус адвоката, правова допомога, юридичні послуги, законодавство.

Постановка проблеми

Прагнення України до євроінтеграції вимагають узгодження системи національного законодавства у сфері прав людини 3 правовими нормами Свропейського Союзу. На цьому шляху однією з умов є організація діяльності адвокатури, як незалежного правового інституту, заснованого на принципах верховенства права, демократизму, захисту прав і свобод людини і громадянина. Невід'ємною частиною демократичної правової держави є забезпечення доступу до правової допомоги та правосуддя. 3 цього огляду, постійне дослідження проблем ор- 


\section{Кримінальне право, кримінальний процес та криміналістика}

ганізації та функціонування інституту адвокатури, який сьогодні діє в системі органів правосуддя, є завжди актуальним.

\section{Мета статті}

Метою цієї статті є висвітлення місця адвокатури у системі органів правосуддя.

\section{Ступінь дослідженості теми}

Окремим питанням правового статусу інституту адвокатури та його взаємовідносин 3 органами судової влади, надання правової допомоги, захисту прав і свобод людини i громадянина присвячені роботи зарубіжних та вітчизняних науковців, зокрема: В.Андрєєвського, О. Бойкова, Т. Варфоломеєвої, А. Козьміних, А. Кучерена, С.Прилуцького, С. Сафулько, О. Святоцького, $\lambda$. Тація та ін. Більшість досліджень було проведено до прийняття Закону України «Про адвокатуру та адвокатську діяльність» 2012 року. У зв'язку з проведенням судової реформи 2016 року і досі багато питань, пов'язаних з інститутом адвокатури, потребують наукового дослідження, що і $\mathrm{E}$ завданням цієї статті.

\section{Виклад основного матеріалу}

Для забезпечення реалізації прав і свобод людини і громадянина Конституцією України встановлено відповідні правові гарантії. Зокрема, у ст. 59 зазначено - кожен має право на правову допомогу. У випадках, передбачених законом, ця допомога надається безоплатно. Кожен є вільним у виборі захисника своїх прав [1]. Згідно зіст. 131-2 Конституції України для надання професійної правничої допомоги в Україні діє адвокатура [1].

Конституція України ст. 124 визначає, що правосуддя в Україні здійснюють лише суди [1]. Проте, у зв'язку з проведенням судової реформи на підставі Закону України «Про внесення змін до Конституції України (щодо правосуддя) від 02.062016 р. № 1401VIII [2], прокуратуру і адвокатуру віднесено до Розділу VIII «Правосуддя» Конституції України.

Законодавець справедливо підмітив, що інститут правової (юридичної) допомоги адвокатури, за своєю конституційною природою і соціально-правовим змістом, знаходиться в тісному взаємозв'язку 3 інститутом судової влади, ефективність якої значною мірою зумовлюється рівнем правової допомоги, яка надається адвокатами. Конституційне право на правову допомогу (ст. 59) справедливо відносить до основних конституційних гарантій право на доступ до правосуддя, яке, у свою чергу, є невід'ємною складовою права на судовий захист (ст. 55) [1]. Хоча судді та адвокати, відповідно до закону, відіграють різну роль у судовому процесі, проте їхній внесок $є$ необхідним для досягнення справедливого та ефективного рішення в усіх судових процесах.

Згідно з ч. 1 ст. 2 Закону України «Про адвокатуру та адвокатську діяльність» від 05.07.2012 № 5076-VI (далі - Закон), адвокатура України є недержавним самоврядним інститутом, що забезпечує здійснення захисту, представництва та надання інших видів правової допомоги на професійній основі, а також самостійно вирішує питання організації і діяльності в порядку, встановленому цим Законом [3].

Науковці вказують на триєдність статусу і завдань адвокатури, розглядаючи іiі як правозахисну діяльність адвокатів, як інститут громадянського суспільства та як самоврядну професійну організацію [4, с. 16-17; 5, с. $169 ; 6$, с. 5]. Тобто українська правова доктрина під адвокатурою розуміє інститут громадянського суспільства, покликаний забезпечувати гарантовані права та свободи людини.

Закон стосується широкого кола осіб, а саме: адвокатів-практиків, осіб, що бажають стати адвокатами, та громадян України у зв'язку з наданням правової допомоги для забезпечення охорони й захисту прав та законних інтересів громадян та юридичних осіб.

Фактично адвокатська діяльність забезпечує публічний інтерес, тобто інтерес суспільства в цілому, шляхом обстоювання приватного інтересу конкретної особи, забезпечує принцип змагальності судового процесу, досягнення істини, охорону прав громадян i, тим самим, працює на створення демократичної правової держави. Як зазначають науковці, адвокатська діяльність 
у конституційному, кримінальному, цивільному, господарському, адміністративному процесі, під час розгляду справ про адміністративні правопорушення, надання інших видів правової допомоги, спрямована не лише на задоволення інтересу однієї окремої особи, а й на реалізацію принципів судочинства, принципів правової держави, забезпечення взаємодії суспільства і держави [7, c. 214].

На адвокатуру, як організоване об'єднання юристів-професіоналів, покладаються певні завдання, виконання яких свідчить про ефективність адвокатської діяльності. Спеціальним і головним завданням $\varepsilon$ забезпечення кваліфікованою юридичною допомогою кожного, хто ії потребує. До загальних завдань можна віднести охорону прав і законних інтересів фізичних і юридичних осіб, дотримання і зміцнення законності, виховання громадян у дусі точного і неухильного виконання законів, повагу до прав, свобод, честі та гідності особи, що сприяє здійсненню правосуддя. Для виконання цих завдань адвокатура виконуе свої функції у різних напрямках діяльності: від надання консультацій до захисту у кримінальному провадженні і представництва у цивільних, господарських та адміністративних справах.

Адвокатура хоча і виконує функцію особливої державної ваги - захист прав і законних інтересів громадян, проте вона не $\epsilon$ державною структурою, а професійним об'єднанням, незалежним від органів влади. Як визначено у ч. 1 ст. 5 Закону: «Адвокатура $є$ незалежною від органів державної влади, органів місцевого самоврядування, їх посадових та службових осіб» [3].

Разом 3 тим, визначення адвокатської професії, як «вільної», у певній мірі є умовним, оскільки мета цього інституту - захищати приватних осіб у правовому спорі $з$ державою, виконуючи, таким чином, публічноправові функції. 3 одного боку, державні органи повинні забезпечувати незалежну роль адвокатів, як гарантію адвокатської діяльності, а 3 іншого - адвокат, як представник правової системи, відповідає перед нею як за свої приватні та комерційні справи, так і за здійснення функцій, делегованих йому державою. Це положення вперше закріплене у Законі: «Держава створює належні умови для діяльності адвокатури та забезпечує дотримання гарантій адвокатської діяльності» (ч. 2 ст. 5) [3]. Адвокат, у разі потреби, мусить бути готовим піддати сумніву правомірність дій держави, якщо вони суперечать демократичним принципам. Однак, він також зобов'язаний не заважати нормальному перебігу правового процесу. Адвокат повинен бути одночасно сумлінним захисником і представником правосуддя та особою, яка забезпечує реалізацію важливого конституційного права - права на правову допомогу. Отже, незалежна судова система може бути створена лише за наявності дійсно незалежної адвокатури. Як слушно зауважує С.В. Прилуцький, саме адвокатура має бути надійною опорою судової влади та правосуддя [8, с. 240].

Звернемо увагу на правову позицію Конституційного Суду України, висловлену у Рішенні № 23-рп/2009 від 30 вересня 2009 р. у справі про правову допомогу [9].

Конституційний Суд України визначив правову допомогу як багатоаспектну, різну за змістом, обсягом та формами, яка може включати консультації, роз'яснення, складення позовів і звернень, довідок, заяв, скарг, здійснення представництва, зокрема в судах та інших державних органах, захист від обвинувачення тощо. Вибір форми та суб'єкта надання такої допомоги залежить від волі особи, яка бажає ії отримати. Таким чином, відповідно до правової позиції Конституційного Суду України термін «правова допомога» має тлумачитися якнайширше і охоплювати будь-яку діяльність, спрямовану на реалізацію правових норм в інтересах тієї чи іншої особи.

Отже, відповідно до правової позиції Конституційного Суду України правова допомога - це юридичні (правові) послуги, а адвокатура є лише одним із суб'єктів, що надає правову допомогу (юридичні послуги). Тому єдиною і головною відмінністю адвокатури, як суб'єкта надання правової допомоги, є, власне, адвокатський статус, тобто сукупність передбачених законом професійних прав, обов'язків i, що найважливіше, гарантій адвокатської 


\section{Кримінальне право, кримінальний процес та криміналістика}

діяльності. Цей особливий статус адвокатури повинен забезпечувати ефективнішу правову допомогу адвоката порівняно 3 юридичними послугами інших суб'єктів. Адвокати також мають відігравати суттєву роль у справедливому відправленні правосуддя в межах свого професійного обов'язку захисту прав та інтересів своїх клієнтів.

Коло, межі і територія адвокатської діяльності встановлюється ст. 19 Закону [3]. Не випадково першим пунктом переліку різновидів адвокатської діяльності Закон називає «надання правової інформації, консультацій і роз'яснень правових питань» [3]. Серед широкого спектру видів адвокатської діяльності, регламентованих Законом, консультаційна робота $є$ найбільш ємким i, такою ж мірою, важливим сектором зайнятості. Це основний вид роботи всіх адвокатів і адвокатських формувань у загальному діапазоні юридичної допомоги населенню. Здебільшого саме з консультаційної роботи починаються всі інші види юридичної практики: надання порад, довідок, складання юридичних паперів та документів, досягнення згоди про подальшу співпрацю, укладення угод про провадження тих чи інших справ у суді тощо - усе це результат роботи адвоката з надання пересічної консультації.

Консультаційна робота породжує й інші види консультаційної допомоги, передбачені законодавством. Наприклад, такий вид, як правовий супровід діяльності юридичних і фізичних осіб, органів державної влади, органів місцевого самоврядування, держави (стаття 19 Закону) [3]

Стосовно правового супроводу - йдеться про юридичну допомогу у вигляді обслуговування за угодою, інакше кажучи, йдеться про юрисконсультство, яке було, є і буде інтенсивно розвиватися.

Дискусійним питання діяльності адвокатури залишається доцільність запровадження адвокатської монополії, доцільність прийнятих змін і порядку ії запровадження в державі. Законом України «Про внесення змін до Конституції України (щодо правосуддя) від 02.062016 р. [2] встановлено, що для надання професійної правничої допомоги діє адвокатура, а ст. 131-2 Конституції України проголошує, що лише адвокати здійснюють захист та представництво в суді, крім випадків, встановлених законом [1].

Необхідно зазначити, що адаптація до нових умов була досить складним процесом. Відповідно до пп.11 п.16-1 Перехідних положень Конституції України представництво лише адвокатами у Верховному Суді та судах касаційної інстанції здійснюється 31 січня 2017 року; у судах апеляційної інстанції - 31 січня 2018 року; у судах першої інстанції - 31 січня 2019 року. Представництво органів державної влади та органів місцевого самоврядування в судах лише прокурорами або адвокатами здійснюеться 31 січня 2020 року. Представництво в суді у провадженнях, розпочатих до набрання чинності Законом України «Про внесення змін до Конституції України (щодо правосуддя)», здійснюється за правилами, які діяли до набрання ним чинності, -до ухвалення у відповідних справах остаточних судових рішень, які не підлягають оскарженню [2].

Необхідно звернути увагу на конституційне положення про те, що законом можуть бути визначені винятки щодо представництва в суді у трудових спорах, спорах щодо захисту соціальних прав, щодо виборів та референдумів, у малозначних спорах, а також стосовно представництва малолітніх чи неповнолітніх осіб та осіб, які визнані судом недієздатними чи дієздатність яких обмежена (ст.131-2 Конституції України) [1].

Судова реформа в Україні передбачала оновлення законодавства, спрямованого на відновлення довіри до судової влади та суміжних правових інститутів, а також комплексну побудову інституційних спроможностей відповідних правових інститутів. Основним аргументом впровадження адвокатської монополії на представництво в судах було надання громадянам саме професійної допомоги та забезпечення доступності до правової допомоги, яка гарантується наявністю великої мережі юридичних установ, здатної забезпечити населення країни всебічною та якісною юридичною допомогою. Зрозуміло, що термін «доступність» передбачає, у тому числі, і ціновий фактор. 
30 жовтня 2019 року Конституційний Суд України визнав законопроєкт №1013 щодо скасування адвокатської монополії таким, що відповідає статтям 157, 158 Основного Закону, а 13 листопада профільний Комітет парламенту рекомендував Верховній Раді попередньо схвалити цей законопроєкт. 14 січня 2021 року Верховна Рада України попередньо схвалила законопроєкт про скасування адвокатської монополії, підтримавши відповідну постанову № 1013/ П1. Законопроєкт передбачає зміни до Конституції України, а саме - нову редакцію статті 131-2.

За новою версією, конституційна норма повинна передбачати наступне: «Для надання професійної юридичної допомоги в Україні діє адвокатура. Незалежність адвокатури гарантується. Основи організації i діяльності адвокатури та здійснення адвокатської діяльності в Україні визначаються законом. Тільки адвокат здійснюе захист особи від кримінального обвинувачення». Фактично 3 норми виключаються положення, за якими тільки адвокати мають право надавати професійну правничу допомогу третім особам у вигляді представництва у судах. Також зміни передбачають вилучення підпункту 11 пункту 16-1 розділу XV «Перехідні положення» Конституції України, якими передбачено поступове впровадження адвокатської монополії.

Сьогодні Президентом України В.Зеленським підписано Указ № 231/2021 «Про Стратегію розвитку системи правосуддя та конституційного судочинства на 20212023 роки» [10]. У документі визначено проблеми, які необхідно розв'язати для впровадження невідкладних заходів для покращення діяльності правових інститутів, подальшого вдосконалення функціонування судової влади, здійснення правосуддя та покращення доступу до правосуддя з урахуванням найкращих міжнародних практик. Одним з напрямів Стратегії є удосконалення інституту адвокатури.

Відповідно до п. 4.5 Стратегії, з метою запровадження системного підходу до удосконалення інституту адвокатури, в Україні необхідно забезпечити:
- посилення гарантій адвокатської діяльності, іiі видів і професійних прав адвокатів, удосконалення самоврядності адвокатури;

- розширення можливостей доступу до державних реєстрів та баз даних при здійсненні адвокатської діяльності;

- конкретизацію підстав, процедур притягнення адвоката до дисциплінарної відповідальності та порядку оскарження рішення про притягнення до такої відповідальності;

- запровадження інституту спрощеного дисциплінарного провадження;

удосконалення порядку розгляду скарг на дії адвоката;

- перегляд вимог щодо набуття права на зайняття адвокатською діяльністю, запровадження прозорої процедури проведення єдиного кваліфікаційного іспиту, стажування кандидатів, порядку ведення Сдиного реєстру адвокатів України;

удосконалення:

- організаційно-правових форм здійснення адвокатської діяльності та засад діяльності органів адвокатського самоврядування, удосконалення професійних стандартів діяльності адвоката;

- порядку та умов залучення адвокатів до надання безоплатної правової допомоги;

- статусу помічника адвоката;

- порядку захисту прав адвоката під час здійснення професійної діяльності [9].

Висновки. Держава, яка керується принципом верховенства права, повинна організувати свою судову систему таким чином, щоб верховенство закону та повага до основоположних прав та свобод людини і громадянина нею гарантувались. Необхідною умовою здійснення реалізації судового захисту прав і свобод людини і громадянина $є$ надання адвокатами професійної правової допомоги. I судді, і адвокати відіграють найважливішу роль у досягненні правосуддя, а тому інститут адвокатури в системі органів правосуддя є ії невід'ємною частиною.

\section{Література}

1. Конституція України 28.06.1996 № 254к/96-ВР /Відомості Верховної Ради України. URL:https://zakon.rada.gov.ua/laws/ card/254 


\section{Кримінальне право, кримінальний процес та криміналістика}

2. Про внесення змін до Конституції України (щодо правосуддя): Закон України від 02.062016 року № 1401-VIII /Відомості Верховної Ради України. URL:https://zakon. rada.gov.ua/laws/show/1401-19\#Text

3. Про адвокатуру та адвокатську діяльність: Закон України від 05.07.2012№ 5076-VI /Відомості Верховної Ради України. URL:https://zakon.rada.gov.ua/laws/ show/5076-17\#Text p

4. Тацій $\curlywedge$. В. Юридична природа адвокатури в системі захисту прав і свобод людини і громадянина: автореф. дис. ... канд. юрид. наук : спец. 12.00.01 «Теорія та історія держави і права; історія політичних і правових учень». Харківський нац. ун-т внутр. справ. Х., 2008. 20 с.

5. Аракелян М. Р. Институт адвокатуры в правозащитной системе Украины: теоретико-правовой аспект: [монография] О.: Феникс, 2014. 280 с.

6. Козьміних А. В. Роль інституту адвокатури в реалізації правозахисної функції громадянського суспільства: автореф. дис. ... канд. політ. наук: спец. 23.00.02 «Політичні інститути та процеси». Одеська нац. юрид. академія. Одеса, 2008. 18 с.

7. Адвокатура України: Книга 1. Організація адвокатури (з практикумом): Підручник у двох книгах / за заг. ред. д.ю.н., проф. заслуженого юриста України С. Я. Фурси та к.ю.н, доцента Бакаянової Н. М. 2-ге вид. доповн. і перероб. К.: Алерта, 2016. 864 с.

8. Прилуцький С. В. Громадянське суспільство в механізмі судової влади та правосуддя: теоретико-правовий аспект.Часопис Київсъкого університету права. 2010. № 1. С. 236-242.

9. Рішення Конституційного Суду України у справі за конституційним зверненням громадянина Голованя Ігоря Володимировича щодо офіційного тлумачення положень статті 59 Конституції України (справа про право на правову допомогу) від 30 вересня 2009 р. № 23-рп/2009 // Офіційний Вісник України. 2009. № 79. Ст. 2694.

10. Про Стратегію розвитку системи правосуддя та конституційного судочинства на 2021-2023 роки: Указ Президента України від 11.06.2021 №231/2021 URL:https://zakon. rada.gov.ua/laws/show/231/2021\#Text

\section{SUMMARY}

The article is devoted to the issue of determining the place of the bar in the justice system. The urgency of this issue was a consequence of the adoption in June 2016 of the Law of Ukraine "On Amendments to the Constitution of Ukraine (concerning justice)" dated 02.06.2016 № 1401VIII, which referred the institute of advocacy to justice.

It is noted that the Bar of Ukraine is a nongovernmental self-governing institution that provides protection, representation and other types of legal assistance on a professional basis, as well as independently decides on the organization and activities in the manner prescribed by law. Advocacy ensures the public interest, ie the interest of society as a whole, by defending the private interest of a particular person, and thus promotes justice.

The Bar has a number of tasks, the main of which is to provide qualified legal assistance to everyone who needs it, to promote justice, compliance and strengthening of the rule of law and their strict implementation in various areas - from counseling to protection in criminal proceedings and representation in civil, economic and administrative affairs.

The definition of the legal profession as "free" is to some extent conditional, as the purpose of this institution is to protect individuals in a legal dispute with the state, performing public law functions. The only and main difference between the bar, as a subject of legal aid, is the legal status and guarantees of advocacy. The special status of the bar should provide more effective legal assistance to a lawyer compared to the legal services of other entities. An independent judiciary can only be established if there is a truly independent bar. The expediency of introducing a lawyer's monopoly and its impact on the administration of justice remains a debatable issue.

The provision of professional legal assistance by lawyers is a necessary condition for the administration of justice, so the institution of the bar in the justice system is an integral part of it.

Key words: advocacy, advocacy activity, judicial reform, status of a lawyer, legal aid, legal services, legislation. 